\title{
Infection Courts of Rice Seedlings with Pseudomonas plantarii and Pseudomonas glumae
}

\author{
Koji Azegami*, Koushi NishiYama* and Hideo TabeI*
}

Key words: infection, stoma, wound, rice, Pseudomonas plantarii, Pseudomonas glumae.

Bacterial seedling blight of rice grown in nursery boxes has occurred annually in Miyagi, Chiba, Niigata, Kyoto, and Yamaguchi Prefectures, Japan ${ }^{1-4)}$. Pseudomonas plantarii was reported to be the causal agent for the disease ${ }^{5}$. However, it has not been shown if $P$. plantarii as well as $\boldsymbol{P}$. glumae, which causes seedling rot of rice ${ }^{(6)}$, actually enters rice seedlings. This paper reports the histological study on the seedling tissues affected with them.

Affected seedlings were prepared in the following manner. Rice seeds, which had been soaked in water at ca. $30 \mathrm{C}$ for 2 days, were placed on $0.5 \%$ agar gel and grown at 25 to $30 \mathrm{C}$ in a laboratory. They were inoculated with Pseudomonas plantarii NIAES 1723 (MAFF 03-01723, JCM 5492, ATCC 43733, ICMP 9424, AZ 8201) or $P$. glumae AZ 84431. Some of them were inoculated at the time of or after 2 days of sowing, with $0.1 \mathrm{ml}$ of the inoculum (ca. $10^{8} \mathrm{CFU} / \mathrm{ml}$ ) per germination. The rest was submerged in the inoculum after 4 days of sowing.

The inoculated seedlings were harvested after 2 to 11 days of inoculation and fixed in formalin-acetic acid-70\% alcohol $(6.5: 2.5: 100)$. After dehydrated in 70 to $100 \%$ alcohol, they were embedded in paraffin and cut into thin section $15 \mu \mathrm{m}$ thick with a microtome. The tissues were stained by using a standard procedure, the Stoughton's method.

The rice seedlings inoculated with $P$. plantarii at the time of or after 2 days of sowing, showed severe symptoms when harvested after 6 to 11 days of the inoculation. Brown streaks were sometimes observed in coleoptiles (Fig. 1 A, B). Histological study revealed that the bacterium entered the seedlings through stomata in the surfaces of coleoptiles or leaf sheaths and through wounds (Plate I B, C, D, E, F, IIA). The entrance of the bacterium into rice seedlings through such stomata seems to occur easily, since some stomata in the surfaces of coleoptiles and leaf sheaths are always open and they allow nonpathogenic bacteria as well as Xanthomonas campestris pv. oryzae to enter the seedlings ${ }^{7}$ ). During the seedling growth, ruptures occur in the surfaces of coleoptiles and roots at the points of emergence of the first leaves or secondary roots. The bacterium entered the seedlings through such wounds (Plate II A). It multiplied and spread intercellularly (Plate I A, C, D, E, II A).

The brown streaks in coleoptiles were due to browning of the parenchyma cells around the vascular bundle sheaths (Plate I F). The brown areas were not always accompanied by the bacterium. The streaks were also observed in the coleoptiles of the seedlings grown on the agar

\footnotetext{
* National Institute of Agro-Environmental Sciences, Tsukuba, Ibaraki 305, Japan 農林水産省農 業環境技術研究所

1) Azegami, K., Nishiyama, K. and Watanabe, Y. (1983). Ann. Phytopath. Soc. Japan. 49: 411.

2) Kadota, I. and Ohuchi, A. (1986). Ibid. 52: 92. 3) Shirata, A., Azegami, K., Honkura, R., Matsuda, I. and Sato, Z. (1986). Ibid. 52: 92-93. 4) Miyagawa, H., Ozaki, K., Kimura, T., Matsumoto, K., Sugiyama, M. and Fukunishi, T. (1987). Ibid. 53: 111-112. 5) Azegami, K., Nishiyama, K., Watanabe, Y., Kadota, I., Ohuchi, A. and Fukazawa, C. (1987). Int. J. Syst. Bacteriol. 37: 144-152. 6) Uematsu, T., Yoshimura, D., Nishiyama, K., Ibaraki, T. and Fujii, H. (1976). Ann. Phytopath. Soc. Japan 42: 310-312. 7) Tabei, H. (1967). Ibid. 33: 12-16.
} 


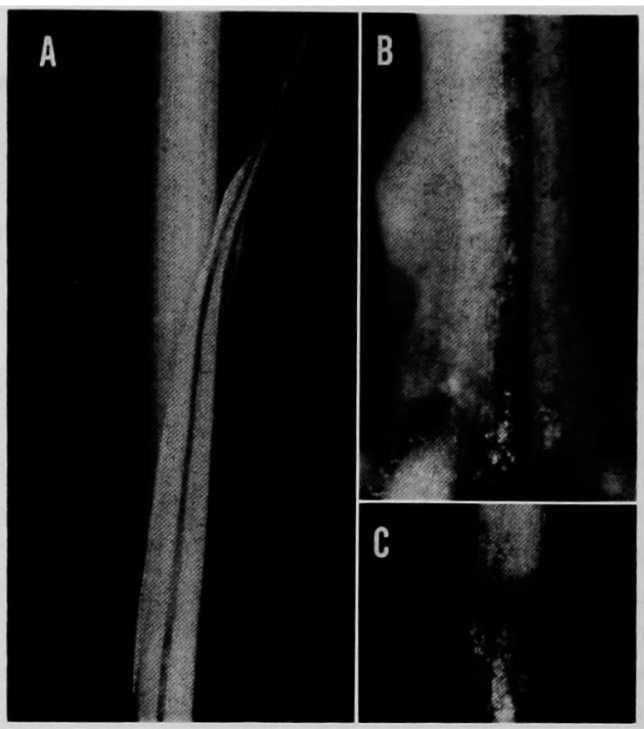

Fig. 1. Symptoms on coleoptiles infected with $P$. plantarii and $P$. glumae. (A) and (B) Brown streak in coleoptile infected with $P$. plantarii. (C) Brown lesion on coleoptile infected with P. glumae.

gel containing tropolone, a product of the pathogen and toxic to rice seedlings ${ }^{8}$. Therefore, the browning of the cells was considered due to the condensation of tropolone in the cells, which was produced in the basal parts of the seedlings and transported through vessels.

The seedlings, which were submerged in the inoculum after 4 days of sowing and harvested after 2 days of the inoculation, did not show any symptoms. But the bacterium entered them through stomata or wounds (Plate I E).

$P$. glumae entered rice seedlings, multiplied, and spread in the same manner. It invaded, rotted, and disintegrated the parenchyma of the first or second leaf sheaths (Fig. 1 C, Plate II B, C, D, E, F). The changes of the tissue were not seen with $P$. plantarii. $P$. glumae has a weak ability to rot potato slices, while $P$. plantarii does not ${ }^{5}$. This seems to be a factor to account for the differences in symptoms. Although the coleoptiles were invaded by $P$. glumae, they usually retained their shapes.

We thank Dr. E. Hamaya, Head of the Division of Microbiology, National Institute of Agro-Environmental Sciences, for his helpful advice in the preparation of the manuscript.

\section{和 文 摘 要}

畔上耕児・西山幸司・田部井英夫：Pseudomonas plantarii および P. glumae のイネ体内への唚入および 增殖部位

Pseudomonas plantarii およびP. glumae を接種したイネ幼苗の連続切片を作成し，これらの細菌の侵入 および增殖部位を顕微鏡観察した。その結果，P. plantarii は，鞴葉および本葉葉䩪の気孔，䩗葉が裂けた

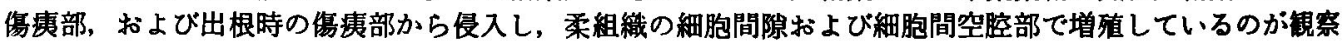
された。䩗葉には褐色条斑が見られたが，それは維管束䩗外側の柔組織細胞の裰変によるすのであった。こ の褐変部には細菌は必ずしも存在していなかった。P.glumae は同様にイネ体内に侵入して，本葉葉献の組 織を腐敗・崩壊させたが, P. plantarii ではそれらは観察されなかった。䩗葉の形態はいずれの細菌を接牦 した場合にも崩れていなかった。

(Received March 2, 1988)

8) Azegami, K., Nishiyama, K., Watanabe, Y., Suzuki, T., Yoshida, M., Nose, K. and Toda, S. (1985). Ann. Phytopath. Soc. Japan 51: 315-317. 


\section{Plate I}
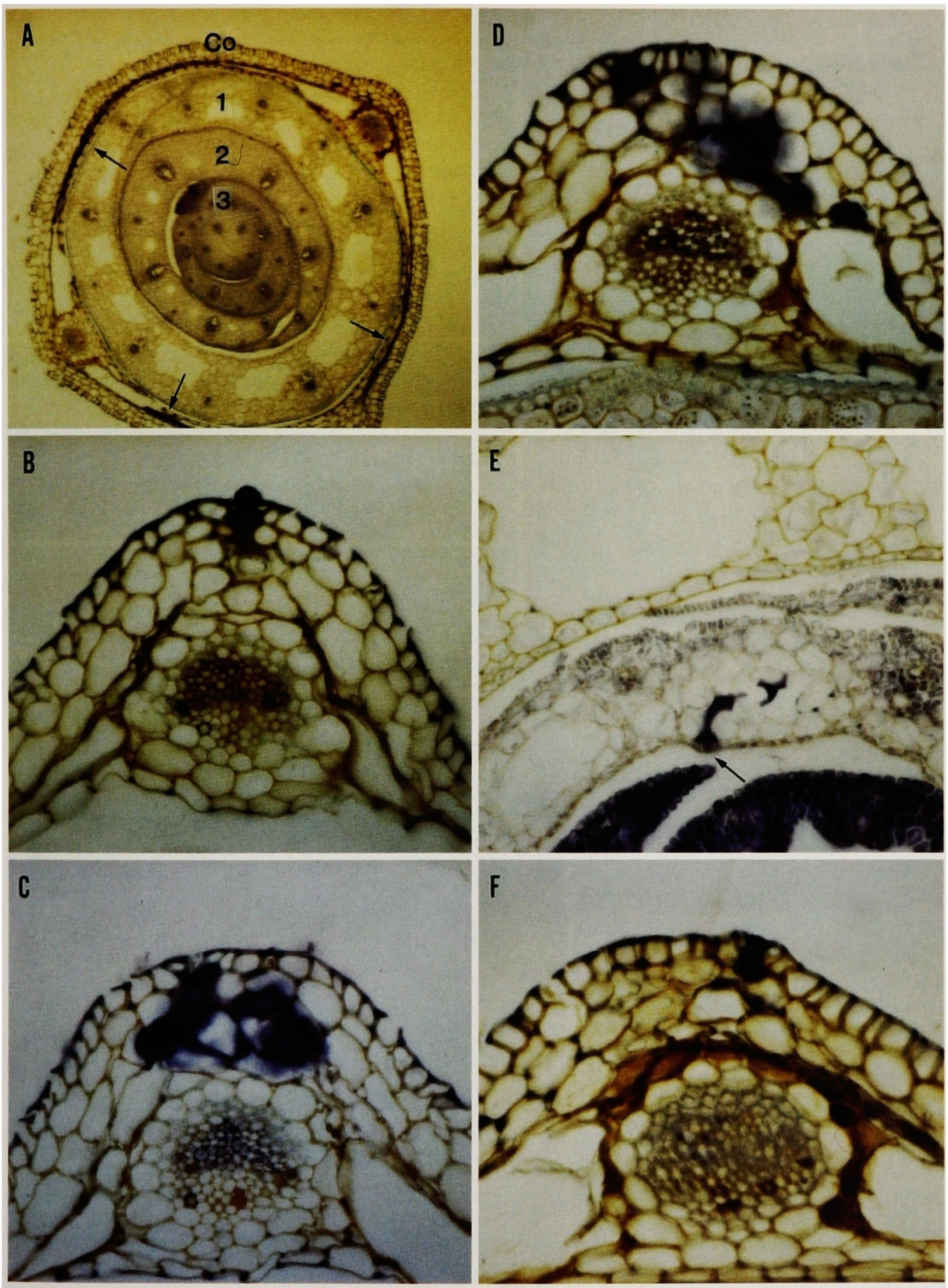


\section{Plate II}

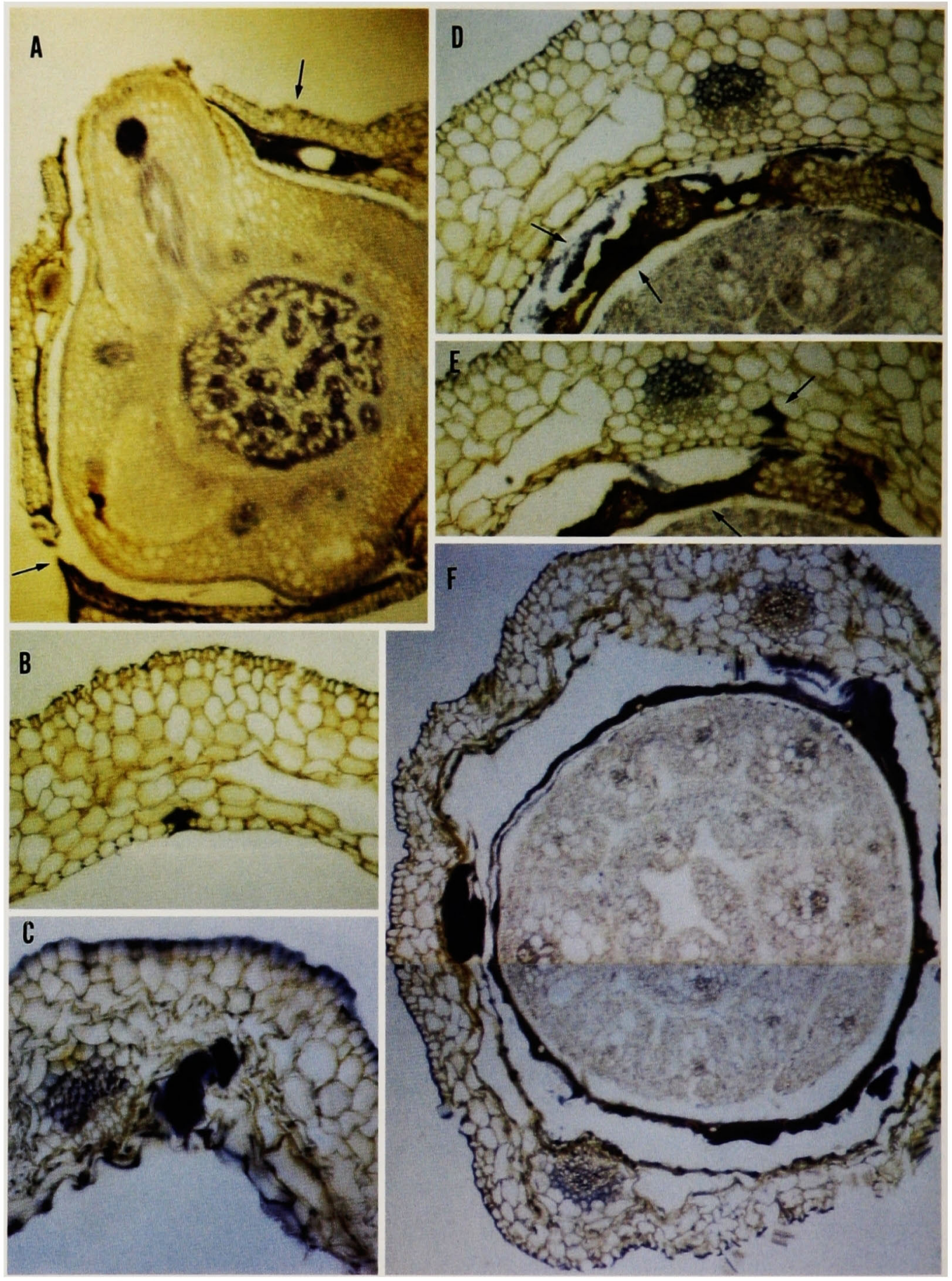




\section{Explanation of plates}

Plate I. Cross sections of rice seedlings inoculated with $P$. plantarii.

A General view. Co, Coleoptile; 1, 2. and 3, first, second, and third leaf sheaths, respectively. B Infection of coleoptile with $P$. plantarii through stoma.

C and D Infection of coleoptile with $P$. plantarii through stoma and multiplication of the pathogen in intercellular spaces of parenchyma.

E Infection of the second leaf sheath through stoma with and multiplication of $P$. plantarii.

F Browning of parenchyma cells around vascular bundle sheath.

Arrows indicate bacterium.

Plate II. Cross sections of rice seedlings.

A Entrance of $P$. plantarii into coleoptile through wound and multiplication in intercellular spaces of coleoptile.

B Infection of coleoptile with $P$. glumae through stoma.

C Multiplication of $P$. glumae in coleoptile.

D, E, and F Disintegration of the first leaf sheath infected with $P$. glumae.

Arrows indicate bacterium. 